\title{
STRATEGI POLITIK IKHWANUL MUSLIMIN TERHADAP KEBIJAKAN PEMERINTAH MESIR PASCA DIGULINGKANNYA MURSI
}

Tholhah

\begin{abstract}
Abstrak
Penelitian ini akan membahas sebuah gerakan politik di Timur Tengah, tepatnya di negara Mesir yang bernama Ikhwanul Muslimin. Penelitian ini hanya dibatasi strategi politik Ikhwanul muslimin setelah lengsernya Presiden Mursi. Teknik pengumpulan data dalam penulisan karya ini menggunakan metode riset perpustakaan (library research), yaitu melalui pengumpulan data dari referensi buku, majalah, jurnal ilmiah dan media cetak lainnya. Strategi politik yang diusung Ikhwanul Muslimin sebagai Gerakan Islam Transnasional dalam merespon penetapan mereka sebagai gerakan Teroris oleh pemerintah mesir pasca digulingkannya Mursi adalah dengan melakukan reaksi baik tingkat domestik (Mesir) dan Internasional karena Ikhwanul Muslimin adalah sebuah Gerakan Transnasional.
\end{abstract}

Kata kunci: Ikhwanul Muslimin, Mesir, Mursi, Strategi politik, Gerakan Islam Transnasional

\section{PENDAHULUAN}

Tanggal 25 Desember 2013 Pemerintah Mesir yang didukung militer mengumumkan Ikhwanul Muslimin sebagai sebuah kelompok teroris. Pemerintah Mesir melarang semua kegiatan Ikhwanul, termasuk demonstrasi. Keputusan itu akan mempercepat operasi penumpasan gerakan Ikhwanul Muslimin tersebut yang telah menewaskan lebih dari seribu orang yang sebagian besar militan dalam bentrokan di jalan. Ribuan orang juga ditahan sejak penggulingan Mursi oleh militer pada Juli 2013. 
Keputusan itu disampaikan sehari setelah serangan bom mobil bunuh diri terhadap kantor keamanan yang menewaskan 16 orang tepatnya pada hari Rabu tanggal 25 Desember 2013, pengumuman itu disampaikan oleh Hossam Eissa, Menteri Pendidikan Tinggi Mesir, membacakan pernyataan Kabinet itu seusai rapat panjang. Ia mengatakan: "Kabinet telah menyatakan kelompok Ikhwanul Muslimin dan organisasinya sebagai organisasi teroris." "Mustahil bagi negara Mesir ataupun rakyat Mesir tunduk pada terorisme Ikhwanul Muslimin," tambah Hossam (VOA 2013).

Ia mengatakan keputusan itu diambil menanggapi pemboman fatal hari Selasa yang menarget markas besar polisi di kota Delta Nil, dimana 16 orang tewas dan lebih 100 lainnya cedera. Ikhwanul membantah mereka bertanggung jawab atas serangan di Mansoura itu, sementara sebuah kelompok al-Qaida hari Rabu mengaku bertanggung jawab atas bom bunuh diri itu.

Bukan hanya itu saja, bahkan Pemerintah interim Mesir berencana meminta Organisasi Kepolisian Kriminal Internasional (Interpol) dan PBB untuk memasukkan Ikhwanul Muslimin (IM) sebagai kelompok teroris dalam daftar mereka. Demikian diungkapkan salah seorang pejabat Departemen Kehakiman Tinggi Mesir, sebagaimana dalam hubungan internasional memiliki sifat dasar mengenai kekuasaan yang akan tercermin melalui pencapaian kepentingan nasional dari pada ideal-ideal yang disepakati (Rachmat 2020).

Bahkan Asisten Menteri Adel Fahmi pada jumat 27 Desember 2013 mengatakan, jika PBB setuju memasukkan IM dalam daftar kelompok teroris, maka Mesir dapat meminta negara lain untuk menangkap anggota organisasi internasional itu. "Termasuk juga meminta negara yang bersangkutan untuk menyita aset mereka," kata Fahmi. Pemerintah interim Mesir juga telah meminta Liga Arab agar memberitahukan negaranegara anggotanya mengenai keputusan soal label 'teroris' terhadap Ikhwanul Muslimin (Jamil \& Mardiani 2013). 
Hal inilah yang merusak demokratisasi karena dengan masuknya kembali militer dalam sebuah pemerintahan maka negara tersebut tidak bisa menjalan demokratisasi dengan baik, jika hal terus berlangsung maka yang terjadi adalah social frustration sehingga akan terjadi kekacauan politik, hal inilah yang di takutkan oleh pemerintah mesir sehingga membuat statement Ikhwanul Muslimin sebagai organisasi Teroris.

Dalam penelitian ini penulis mengharapkan dapat memberikan gambaran tentang isu - isu yang muncul dalam dunia Islam yang terglobalisasi dewasa ini dan memberikan penjelasan tentang respon Ikhwanul Muslimin setelah ditetapkannya sebagai gerakan terroris oleh pemerintah Mesir pasca digulingkannya Mursi baik yang ada di Mesir dan berbagai Negara. Serta memberikan pandangan tentang strategi Ikhwanul Muslimin dalam memobilisasi gerakannya diberbagai Negara sebagai sebuah gerakan Transnasional yang mendukung penolakan Ikhwanul Muslimin sebagai Gerakan Terrois oleh pemerintah Mesir pasca digulingkannya Mursi.

\section{Strategi Politik Ikhwanul Muslimin Yang Ada di Mesir}

Penetapan Ikhwanul Muslimin sebagai organisasi teroris itu disampaikan sehari setelah serangan bom mobil bunuh diri terhadap kantor keamanan yang menewaskan 16 orang tepatnya pada hari Rabu tanggal 25 Desember 2013, pengumuman itu disampaikan oleh Hossam Eissa, Menteri Pendidikan Tinggi Mesir, membacakan pernyataan Kabinet itu seusai rapat panjang. Ia mengatakan: "Kabinet telah menyatakan kelompok Ikhwanul Muslimin dan organisasinya sebagai organisasi teroris." "Mustahil bagi negara Mesir ataupun rakyat Mesir tunduk pada terorisme Ikhwanul Muslimin," tambah Hossam (VOA 2013). Ia mengatakan keputusan itu diambil menanggapi pemboman fatal hari

Selasa yang menarget markas besar polisi di kota Delta Nil, dimana 16 orang tewas dan lebih 100 lainnya cedera. Ikhwanul membantah mereka 
bertanggung jawab atas serangan di Mansoura itu, sementara sebuah kelompok al-Qaeda hari Rabu mengaku bertanggung jawab atas bom bunuh diri itu.

Ikhwanul Muslimin sebagai gerakan sosial dan politik ketika dituduh sebagai organisasi teroris maka yang dilakukan adalah dengan melakukan aksi demonstrasi sebagai aksi penolakan tersebut, hal ini sesuai yang diungkapkan oleh Sidney Tarrow dalam mendefinisikan social movement sebagai tantangan bersama (untuk elit politik, penguasa, atau kelompok kebudayaan tertentu) oleh orang-orang dengan tujuan bersama dan solidaritas dengan interaksi yang terus-menerus terhadap lawan politik mereka. Dalam hal ini yang dimaksud dengan lawan politik Ikhwanul Muslimin adalah pemerintah mesir yang terlalu berlebihan, bahkan ketika Ikhwanul Muslimin melakukan demonstrasi untuk menentang penetapan sebagai organisasi teroris yang dilakukan adalah dengan menangkap para demonstran dan bahkan dihukum mati.

Berbagai media Arab melaporkan aksi demo pendukung Ikhwanul Muslimin di berbagai wilayah Mesir dan sikap pasukan keamanan negara ini yang menumpas aksi warga tersebut. Seperti dilaporkan MNA mengutip Al Jazeera, berbagai provinsi Mesir Jumat (9/5) dilanda gelombang demo pendukung Ikhwanul Muslimin. Para demonstran di Provinsi Giza, al-Sharqiyah, al-Minya, Alexandria dan Kairo seraya membawa atribut bundaran Rabiah al-Adawiyah dan poster Muhammad Mursi, presiden terguling, menuntut dikembalikannya pemerintahan legal dan pilihan rakyat serta dibubarkannya pemerintahan militer serta kudeta (IRIB 2014).

Pendukung Ikhwanul Muslimin juga mengecam pencalonan Abdul Fattah al-Sisi dan menyatakan selama tuntutan mereka belum dipenuhi, maka aksi demo akan terus dilanjutkan. Aksi demo ini berujung pada kekerasan ketika pasukan keamanan dan polisi Mesir menindak keras demonstran dengan melempari mereka dengan gas air mata serta 
melepaskan tembakan dengan peluru plastik ke arah demonstran (IRIB 2014).

Para demonstran tersebut ditangkap dan divonis mati mati oleh pengadilan Mesir, sebagaimana yang dilaporkan oleh media. Pengadilan Mesir telah merekomendasikan hukuman mati terhadap 683 pria, termasuk pemimpin Ikhwanul Muslimin, Mohamed Badie. Ini merupakan vonis massal kedua berkenaan protes rusuh pasca penggulingan Presiden Mohamed Morsi dan penetapan sebagai teroris pada tahun lalu.

Sebuah peradilan terpisah juga menyatakan sebuah kelompok oposisi sekuler kunci sebagai partai terlarang, dalam tindakan keras yang berkelanjutan terhadap para pengecam pemerintah. Sanak-saudara para terdakwa yang berada di luar gedung pengadilan di Minya, sebelah selatan Kairo, pingsan mendengar keputusan tersebut. Orang-orang lain memprotes keras vonis tadi dan membela para terdakwa yang menurut mereka tidak bersalah.

Rekomendasi hakim itu belum final. Juga hari Senin, pengadilan yang sama membatalkan hukuman mati sebuah kasus terkait, dengan 492 dari 529 pria kini diancam hukuman penjara 25 tahun hingga hukuman seumur hidup. Hukuman mati terhadap 37 pria ditegakkan. Kedua kasus itu terkait dengan pembunuhan seorang polisi dalam protes dan kerusuhan tahun lalu, menyusul tergulingnya tokoh Ikhwanul Muslimin, mantan Presiden Mohamed Morsi.

Organisasi-organisasi HAM dan negara-negara Barat mengecam kedua proses peradilan tersebut, proses cepat di mana para pengacara terdakwa tidak diizinkan memaparkan pembelaan mereka. Berbicara di luar gedung pengadilan, pengacara para terdakwa Mohamed Abdel Wahab mengatakan bahwa hak para terdakwa untuk pembelaan telah dilanggar seraya menambahkan, biasanya, sebuah kasus pembunuhan memakan waktu satu atau dua tahun, tetapi ini selesai hanya setelah sidang pertama. 
Para pengecam mengemukakan, sistem hukum Mesir makin mengikuti keinginan pemerintah yang didukung militer dan kandidat presiden mantan menteri pertahanan Abdel Fattah el-Sissi. Analis politik dan diplomat veteran, Abdallah al-Ashaal mengungkapkan, Sissi dapat menempuh salah satu dari dua cara dalam menangani kelompok Ikhwanul Muslimin, setelah kemenangan pemilu, yang diduga kuat akan diraihnya bulan depan. "Dia mungkin akan secara total menghancurkan Ikhwanul Muslimin, terutama karena begitu banyak mitra, baik dari dalam maupun luar Mesir, yang mengharapkan Sissi melakukannya, atau mereka akan berusaha membesar-besarkan masalah, sehingga Sissi akan keluar sebagai pahlawan dalam menumpas Ikhwanul Muslimin, kemudian memberi amnesti kepada semua," ujar al-Ashaal (Arrott 2014).

Gagasan tentang sebuah kemungkinan bahwa pemerintah dan para penentangnya akan rujuk tampak mengecil sewaktu sebuah peradilan lain, hari Senin, menyatakan sebuah partai sekuler yang pro-demokrasi sebagai partai terlarang. Media pemerintah menyebutkan, "Gerakan 6 April," yang ikut berperan dalam pemberontakan tahun 2011 yang menggulingkan pemimpin yang lama berkuasa, Presiden Hosni Mubarak, telah menodai citra pemerintah (Arrott 2014).

Pengadilan memerintahkan disitanya markas kelompok itu dan menyatakan ilegal segala aktivitasnya. Salah seorang pemimpin kelompok itu, Ahmed Maher, telah divonis tiga tahun penjara karena melakukan unjuk rasa tanpa izin. Pemerintah Mesir mengabaikan semua kecaman terkait tindakan keras terhadap kelompok-kelompok oposisi, berargumen bahwa tindakan tegas diperlukan untuk menegakkan stabilitas. Ratusan, mungkin ribuan orang, banyak di antaranya pendukung Mursi, tetapi juga para anggota pasukan keamanan, telah tewas sejak tergulingnya Mursi. Ribuan lagi mendekam dalam penjara. Mantan presiden itu juga sedang diadili menyangkut beberapa kasus, dan jika dinyatakan bersalah, dapat diancam hukuman mati. 
Namun hal ini mendapat kecaman dari PBB, Sikap permusuhan dan kebencian pemerintah baru Mesir terhadap kelompok Ikhwanul Muslimin yang tampak jelas dalam tindakan keras mereka seperti penangkapan dan vonis mati massal terhadap anggota dan pendukung kelompok tersebut telah menuai kecaman PBB. Sebuah kelompok yang terdiri dari delapan pakar Hak Asasi Manusia PBB mengungkapkan kekhawatiran mendalam atas vonis mati massal terhadap 183 anggota Ikhwanul Muslimin di Mesir. Mereka menilai keputusan tersebut sebagai faktor untuk mendiskreditkan peradilan Mesir. Kelompok para pakar HAM itu juga menuntut persidangan yang adil terhadap anggota Ikhwanul Muslimin di pengadilan yang benar-benar independen dan tidak memihak.

Jika melihat catatan dan rekam jejak peradilan Mesir terkait Ikhwanul Muslimin selama setahun terakhir, maka dengan mudah dapat dipahami bahwa pemerintahan Mesir saat ini tengah berusaha menghapus Ikhwanul Muslimin dari kancah politik. Klaim bahwa Ikhwanul Muslimin mengancam keamanan adalah dalih untuk merealisasikan tujuan tersebut. Pada awal bulan Juni, sebuah pengadilan Mesir memutuskan hukuman mati terhadap 183 anggota Ikhwanul Muslimin termasuk Mohammad Badie, pemimpin kelompok tersebut. Vonis itu dikeluarkan ketika para terdakwa tidak diberi izin untuk membela diri. Dengan demikian, keabsahan peradilan Mesir dipertanyakan.

Pemerintah Mesir mengklaim bahwa anggota-anggota Ikhwanul Muslimin yang dihukum mati telah membuat kekacauan dan terlibat dalam bentrok bersenjata serta mengancam keamanan nasional. Tuduhan tersebut dilontarkan ketika Ikhwanul Muslimin sendiri pada dasarnya tidak percaya pada konflik bersenjata. Setelah tergulingnya Muhammad Mursi, Presiden terpilih Mesir, Ikhwanul Muslimin mengungkapkan penentangan mereka terhadap kudeta terhadap Mursi hanya melalui demonstrasi damai. Namun pemerintah baru Mesir mengambil kebijakan keras terhadap Ikhwanul Muslimin, bahkan memusuhi kelompok 
tersebut. Mereka mempersempit ruang gerak Ikhwanul Muslimin dengan melarang aktivitas kelompok itu.

Saat ini, pemimpin-pemimpin senior Ikhwanul Muslimin dan anggota biasa lainnya mendekam di penjara. Mursi yang juga dipenjara selama hampir setahun ini telah beberapa kali diadili atas tuduhan pembunuhan terhadap warga Mesir. Ia juga dituduh melanggar HAM. Terkait tuduhan tersebut, muncul pertanyaan bahwa bukankah pemerintah Kairo selama setahun lalu juga telah melanggar HAM. Penangkapan besar-besaran terhadap oposisi adalah contoh nyata atas pelanggaran HAM yang dilakukan pemerintah baru Mesir. Tindakan tersebut bahkan dikecam oleh para pendukung pemerintah baru Kairo di tingkat internasional. Amerika Serikat yang menyambut pemerintahan militer di Mesir dan bahkan menyatakan kegembiraan atas terpilihnya Abdel Fattah El Sisi sebagai Presiden baru Mesir, telah berulang kali mengkritik pelanggaran HAM dan penanganan peradilan Mesir terhadap demonstran dan oposisi. Washington juga menuntut perlindungan terhadap hak-hak warga Mesir (Arrott 2014).

Tak diragukan lagi, berlanjutnya kebijakan keras terhadap oposisi di Mesir akan memperdalam kesenjangan yang ada di negara Afrika Utara tersebut. Kondisi itu bahkan tidak hanya akan memperparah krisis di Mesir tetapi juga akan memunculkan pandangan pesimis terhadap pemerintah baru. Berkuasanya kembali militer di Mesir telah cukup sensitif dan rentan, sebab, bagi rakyat Mesir, kondisi itu telah mengingatkan mereka atas masa pemerintahan para jenderal di Negeri Seribu Menara itu, yaitu para jenderal yang telah berkuasa selama tiga dekade dan membungkam setiap suara oposisi. Kini, rakyat mesir kembali di bawah bayang-bayang pemerintahan militer seperti di masa rezim diktator Hosni Mubarak.

Tindakan Ikhwanul Muslimin bukan hanya berhenti sampai disitu (demonstrasi), tapi juga melakukan tindakan dengan mengadukan ke mahkamah Internasional. Hal ini bisa dilihat dari Sejumlah pengacara 
Ikhwanul Muslimin telah mengadukan militer Mesir ke Mahkamah Kriminal Internasional (ICC), atas dugaan kejahatan terhadap kemanusiaan, demikian dikatakan organisasi itu di London, Inggris. Pengacara dari Partai Kebebasan dan Keadilan, partai yang berafiliasi ke Ikhwanul Muslimin, mengatakan berharap bisa bertemu dengan jaksa dari ICC dalam beberapa bulan ke depan untuk membahas penyelidikan awal terhadap kasus tersebut (Jemadu 2014).

Dalam sebuah konferensi pers para pengacara itu mengatakan telah mengajukan sebuah deklarasi atas nama presiden terguling Muhammad Mursi, yang menyatakan bahwa Mesir mengakui yurisdiksi ICC walaupun Mesir tidak meratifikasi statuta ICC dan Mursi sudah tidak berkuasa lagi di negara itu. Para pengacara itu juga mengajukan buktibukti tindak kriminal yang dilakukan militer sejak Mursi dan partainya disingkirkan pada 3 Juli 2013. "Pesan harus disampaikan dengan jelas kepada rezim militer Mesir bahwa mereka juga bisa diadili," kata John Dugard, salah pengacara Ikhwanul Muslimin (Jemadu 2014).

Lebih dari 1000 orang telah tewas dalam kerusuhan jalanan dan ribuan orang dipenjara sejak kepolisian mengejar dan menangkapi para aktivis Ikhwanul Muslimin di Mesir pasca-lengsernya Mursi. Bulan lalu pemerintah Mesir, yang didukung oleh militer, menyatakan bahwa Ikhwanul Muslimin adalah organisasi teroris. Para pengacara Ikhwanul Muslimin di London itu dipimpin oleh Tayab Ali, dari kantor hukum hak asasi manusia, ITN Solicitors. Ia mengaku pendanaan mereka berasal dari para korban kekerasan militer di Mesir. Mesir belum meratifikasi statuta ICC dan Mursi sudah tidak lagi berkuasa di negaranya, sehingga nasib aduan para pengacara itu belum bisa dipastikan. Akan tetapi para pengacara yakin bahwa pemerintahan Mursi masih sah, karena dia terpilih secara demokratis dalam pemilu 2012.

ICC yang berbasis di Den Haag, Belanda, mengatakan bahwa negara yang tidak menandatangani statuta ICC bisa mengakui yurisdiksi lembaga itu untuk mengusut kasus yang terjadi di dalam wilayah negaranya atau 
terhadap salah satu warga negaranya. Pengaduan yang disampaikan pada 20 Desember 2013 itu berisi bukti-bukti dugaan pembunuhan, penahanan ilegal, penyiksaan, penangkapan, dan penghilangan paksa terhadap sejumlah orang oleh rezim militer Mesir. Pada 14 Agustus 2013 sekitar 627 orang terbunuh ketika petugas keamanan menyerbut lapangan Rabaa al Adawiya yang menjadi kamp pendukung Mursi di Kairo. Peristiwa itu adalah pembunuhan massal terbesar dalam sejarah Mesir modern. Dalam aduannya para pengacara itu menyebut sejumlah tersangka, tetapi mereka menolak untuk mengungkapnya di publik.

Strategi politik Ikhwanul Muslimin ini dalam masyarakat global bisa dikategorikan sebagai sebagai strategi pasif dan strategi aktif karena Strategi mobilisasi masyarakat sipil global secara umum terbagi menjadi dua, yaitu strategi mobilisasi aktif dan strategi mobilisasi pasif. Strategi mobilisasi aktif cenderung digunakan oleh masyarakat sipil global dimana dalam strategi ini terdapat adanya isu-isu dan tujuan yang juga disertai dengan tindakan konkrit menuju perubahan. Sedangkan strategi mobilisasi pasif biasanya hanya digunakan dalam beberapa kasus seperti contohnya mogok makan, jahit mulut, dan sebagainya. Strategi mobilisasi aktif bisa juga dikatakan sebagai bentuk dari hard power dalam social movement, dan strategi mobilisasi pasif dapat dikatakan sebagai bentuk dari soft power dalam social movement (Puspitasari 2012).

\section{Strategi Politik Ikhwanul Muslimin di Luar Mesir}

Ikhwanul Muslimin ketika ditetapkan sebagai organisasi teroris bukan hanya mengundang reaksi Ikhwanul Muslimin yang ada di Mesir saja karena Ikhwanul Muslimin sebagai Gerakan Islam Transnasional mampu melebarkan sayapnya sampai ke berbagai penjuru dunia atau sebagai organisasi Internasional, hal ini dikarenakan Ikhwanul Muslimin dapat memenuhi syarat sebagai mana yang dijelaskan oleh Sidney Tarrow:

1. Ide-ide yang ditawarkan organisasi bisa melakukan difusi (menyebar) kepada masyarakat (penyebaran ide). Harus ada 
penyebaran, pergerakan terhadap batas-batas Negara jika ingin menjadi organisasi transnasional

2. Mobilisasi internasional. Terdapat tanggal khusus sehingga masyarakat internasional dapat merayakan bersama-sama. Seperti milad Muhammadiyah yang dirayakan oleh orang Cina dan Malaysia.

3. Modularity (kekhasan, kesamaan dari beberapa hal). Contohnya seperti orang-orang salafi yang para lelakinya memakai pakaian diatas mata kaki. Perempuan salafi identic dengan pakaian dan jilbab warna gelap. Berbeda dengan Muhammadiyah yang belum memiliki ciri khas sehingga sulit untuk dibedakan bahwa Ia orang Muhammadiyah atau bukan.

Ketika Ikhwanul Muslimin di tuduh sebagai gerakan teroris maka yang paling menentang dari luar Mesir adalah Ulama berpengaruh yang tinggal di Qatar, Syaikh Yusuf Qaradhawi menyerukan warga Mesir untuk tidak memilih dan memboikot pemilihan presiden dan menghindari capres hasil kudeta, Jendral. Abdul Fattah As Sisi.

Ulama kelahiran Mesiryang memiliki hubungan dekat dengan Ikhwanul Muslimin ini di Televisi Al Jazeera yang disaksikan oleh jutaan, telah bersikap kritis terhadap pemerintah yang didukung militer Mesir, mengatakan bahwa as Sisi melakukan pengkhianatan untuk mengusir Presiden Muhammad Mursi tahun lalu.

Dukungan vokal Qaradawi untuk Ikhwan baru-baru ini telah memberikan kontribusi terhadap keretakan diplomatik belum pernah terjadi sebelumnya antara Qatar dan perusahaan Teluk Arab sekutu yang menganggap kelompok ancaman keamanan dan didukung penggulingan Mursi. "Orang-orang Mesir di ibukota dan provinsi, kota dan desa, semuanya duduklah saja di rumah Anda dan jangan membebani dirimu dengan dosa besar ..., " kata Qaradawi dalam sebuah pernyataan email. 
"Hal ini tidak diperkenankan bagi Anda untuk memilih dia yang tidak menaati Allah, " tambahnya (Al-Hikmah 2014).

As Sisi sendiri diprediksi dengan mudah memenangkan pemilihan presiden 26-27 Mei, karena Satunya penantang adalah politisi sayap kiri Hamdeen Sabahi, yang datang ketiga dalam 2012 suara dimenangkan oleh Mursi. Sejak Mursi digulingkan, pemerintah yang didukung militer baru telah menindak keras pada Ikhwanul Muslimin, salah satu kekuatan terorganisir terbaik di negara itu. Militer menuduh anggota IM mengobarkan kekerasan dan kerusuhan, ribuan tewas atau ditangkap oleh pasukan keamanan.

Ikhwanul Muslimin mengatakan As Sisi mendalangi kudeta Mursi, yang menjadi presiden pertama Mesir yang dipilih secara demokratis. "Tugas negara adalah untuk melawan para penindas, menahan tangan mereka dan membungkam lidah mereka," kata Qaradawi yang sebelumnya mengatakan ia hanya mendukung perlawanan damai di Mesir. "Saya menolak untuk berpartisipasi dalam pemilu, saya tidak akan pergi untuk berpartisipasi dalam ketidakadilan, " tegasnya (Al-Hikmah 2014).

Dukungan dari Qatar bukan hanya datang dari Yusuf Qaradawi tapi juga dari Ikhwanul Muslimin Qatar yang meminta pemerintah melindungi tokoh - tokoh penting ikhwanul Muslimin, lantas Qatar meminta tujuh tokoh senior Ikhwanul Muslimin meninggalkan negeri tersebut. Sebuah perubahan sikap yang diambil Qatar yang selama ini melindungi Ikhwanul Muslimin. Qatar tak dapat menahan tekanan berbulan-bulan yang dilakukan negara-negara Teluk. Negara-negara itu tak menghendaki Ikhwanul Muslimin memperoleh perlindungan dari Qatar. Sebab, kelompok Islam ini dianggap ancaman. Mesir telah membekukan dan melarang keberadaan Ikhwanul Muslimin. Meski demikian, Ikhwanul Muslimin tak merespons negatif perubahan kebijakan Qatar ini. 
Pejabat senior Ikhwanul Muslimin di London, Inggris, Ibrahim Munir menyatakan, ini bukan berarti perpecahan hubungan Ikhwanul Muslimin dan Qatar. "Qatar menyatakan kepada kami, mereka menghadapi tekanan," kata Munir, Sabtu. Kondisi ini membuat Doha terpaksa meminta tokoh-tokoh senior Ikhwanul Muslimin pergi. Para pejabat Qatar belum menyampaikan pernyataan mengenai berita ini. Pascakudeta terhadap Presiden Muhammad Mursi yang berasal dari Ikhwanul Muslimin oleh militer di Mesir tahun lalu, hanya Turki dan Qatar yang mendukung Ikhwanul Muslimin. Arab Saudi, Uni Emirat Arab, dan negara-negara Teluk lainnya tak menghendaki Ikhwanul Muslimin berkuasa di Mesir. Mereka bahkan mengucurkan dana miliaran dolar AS untuk pemerintahan baru. Mereka menganggap, Ikhwanul Muslimin merupakan ancaman bagi pemerintahan monarki di Timur Tengah.

Dukungan Qatar terhadap Ikhwanul Muslimin membuat Arab Saudi, Bahrain, dan Uni Emirat Arab menarik duta besarnya dari Doha pada Maret lalu. Karena melindungi Ikhwanul Muslimin, hubungan Qatar dan Mesir juga memburuk. Sebab, Qatar membuka pintu bagi tokoh-tokoh penting Ikhwanul Muslimin setelah terjadi kudeta oleh militer Mesir. Militer juga memberangus gerakan Ikhwanul Muslimin dan menetapkannya sebagai kelompok teroris. Ribuan anggota gerakan Islam ini sekarang mendekam di penjara.

Demi menjaga kehormatan Qatar, para tokoh senior Ikhwanul Muslimin sepakat untuk meninggalkan negara itu. "Tokoh-tokoh senior yang diminta pergi, bersedia memenuhi permintaan itu," ujar salah seorang tokoh senior Ikhwanul Muslimin Amr Darrag melalui akun Facebook-nya (Kisihandi 2014).

Menurut Ibrahim Munir, Darrag merupakan salah satu dari tujuh tokoh yang diminta pergi. Meski demikian, Darrag tak menyebutkan secara spesifik dirinya termasuk yang diminta meninggalkan Qatar dalam 
pesan yang diunggah di media sosial. Juru bicara Kementerian Luar Negeri Mesir enggan menanggapi kebijakan Qatar. Mereka menyatakan, akan meminta konfirmasi terlebih dahulu kepada Pemerintah Qatar. Ebtesam al-Ketbi dari Emirates Policy Centre, Abu Dhabi, menyatakan, langkah Qatar bukan menandakan berakhirnya dukungan kepada Ikhwanul Muslimin."Ini hanya untuk menurunkan ketegangan hubungan dengan negara-negara Teluk" (Kisihandi 2014).

Ini cara mobilisasi Gerakan Islam Tradisionalis, ketika ada suatu masalah maka yang lain pun ikut merasakan hal yang sama apalagi yang ada di Induk. Dalam hal ini Ikhwanul Muslimin Mesir sebagai kekuatan politik besar di Mesir, ketika di tuding sebagai gerakan teroris maka Ikhwanul Muslimin yang berada diluar Mesir pun merespon dalam hal ini adalah Yusuf Qaradawi dan pernyataan beliau ditanggapi oleh jamaah Ikhwanul Muslimin yang ada di Mesir untuk tidak berpartisipasi dalam pemilu setelah digulingkannya Mursi. Bahkan Qatar juga memberikan bantuan yang sangat berharga, yakni memberikan perlindungan bagi tokoh - tokoh penting Ikhwanul Muslimin.

\section{Kesimpulan}

Kesimpulan dari hasil analisis penelitian sebagai jawaban terhadap pokok permasalahan yang diangkat : strategi politik Ikhwanul Muslimin sebagai Gerakan Islam Transnasional ketika dituding sebagai organisasi teroris oleh pemerintah mesir pasca digulingkannya Mursi. Reaksi yang ditimbulkan berbagai macam, apalagi hal ini pertamakali ketika pemilihan secara demokratis namun hanya berjalan kurang dari satu tahun karena berbagai hal sehingga banyak demonstrasi yang menuntut mundurnya presiden Mursi yang memimpin roda Pemerinthan mesir pada saat itu. Begitu banyaknya aksi demonstrasi sehingga membuat ketidak stabilan politik Mesir dan membuat geram militer pada saat itu dan melakukan kudeta yang dipimpin oleh menteri pertahan yang ditunjuk oleh presiden 
Mursi yakni jendral El Sisi, yang sekarang menjabat sebagai presiden Mesir. Kemudian pemerintah Mesir penangkap anggota Ikhwanul Muslimin lebih dari 500 orang dan dihukum mati dan menuding Ikhwanul Muslimin sebagai organisasi teroris, adapun strategi politik yang dilakukan Ikhwanul Muslimin ketika dituduh sebagai organisasi teroris pasca digulingkannya Mursi adalah, sebagai berikut:

1. Strategi politik Ikhwanul Muslimin didalam Mesir adalah dengan mengunakan soft power dan hard power dalam social movement yakni dengan melakukan aksi unjuk rasa menuntuk dibebaskannya anggota Ikhwanul Muslimin yang ditangkap oleh militer Mesir serta juga dihindarkan dari hukuman mati, dalam hal ini pun PBB mengutuk keras atas apa yang dilakukan oleh pemerintah Mesir terhadap oposisi (Ikhwanul Muslimin). Ikhwanul Muslimin juga melakukan gugatan ke mahkamah internasional atas pelanggaran HAM yang dilakukan oleh pemerintah Mesir yang dipimpin oleh presiden El Sisi. Strategi politik inilah yang disebut strategi pasif dan aktif karena Strategi mobilisasi aktif cenderung digunakan oleh masyarakat sipil global dimana dalam strategi ini terdapat adanya isu-isu dan tujuan yang juga disertai dengan tindakan konkrit menuju perubahan. Sedangkan strategi mobilisasi pasif biasanya hanya digunakan dalam beberapa kasus seperti contohnya mogok makan, jahit mulut, dan sebagainya.

2. Strategi politik Ikhwanul Muslimin diluar Mesir adalah dengan memberikan dukungan kepada Ikhwanul Muslimin yang ada di Mesir apalagi mereka sedang mengalami kondisi politik yang tidak menyenangkan yakni dituduh sebagai gerakan teroris oleh pemerintah mesir dan banyaknya penahan yang dilakukan oleh pemerintahan tersebut, sebagai Gerakan Islam Transnasional maka yang dilakukan Ikhwanul Muslimin diluar mesir adalah memberi masukan serta bantuan, hal ini bisa dilihat ketika Yusuf Qaradawi yang menginstruksikan agar para pendukung Ikhwanul 
Muslimin tidak mengikuti pemilihan umum, apalagi Yusuf Qaradawi orang yang sangat berpengaruh di Timur Tengah dan Yusuf Qaradawi juga salah satu pendukung ikhwanul Muslimin. Hal lain yang dilakukan Ikhwanul Muslimin diluar Mesir apalagi Qatar untuk melindungi tokoh-tokoh penting Ikhwanul Muslimin, walau banyak yang mengecam hal ini dari negara-negara timur tengah yang pro terhadap pemerintah Mesir.

Dengan demikian dapat disimpulkan bahwa strategi politik Ikhwanul Muslimin ketika dituduh sebagai organisasi teroris pasca digulingkannya Mursi oleh pemerintah Mesir adalah dengan melakukan soft power dan hard power, ini cara mobilisasi Gerakan Islam Transnasional, ketika ada suatu masalah maka yang lainpun ikut merasakan hal yang sama apalagi yang ada di Induk. Dalam hal ini Ikhwanul Muslimin Mesir sebagai kekuatan politik besar di Mesir, ketika di tuding sebagai gerakan teroris maka Ikhwanul Muslimin yang berada diluar Mesir melakukan respon terhadap apa yang terjadi terhadap Ikhwanul Muslimin yang ada di Mesir dengan cara yang berbeda dengan organisasi teroris yang terlihat arogan dan mengancam keamanan negara tersebut.

\section{DAFTAR PUSTAKA}

Armajani, Jon, 2012, Modern Islamist movements : history, religion, and politics, UK : Wiley-Blackwell.

Arrott, Elizabeth. 2014. 'Mesir Hukum Mati 683 Pendukung Ikhwanul Muslimin', dalam VOAIndonesia.com, dilihat 24 Mei 2020 , dari http://www.voaindonesia.com/content/mesir-hukum-mati-683pendukung-ikhwanul-muslimin/1902531.html

Azyumardi Azra dalam jurnal "Muhammadiyah: Tantangan Islam Transnasional" dalam kumpulan jurnal Maarif vol 4 no.2 - desember 2009

Berita Satu. 2014. 'Kejatuhan Morsi dan Kegagalan Gerakan Islamis', dalam Beritasatu.com, dilihat 24 Mei 2020, dari 
http://www.beritasatu.com/blog/nasional-internasional/2636-

kejatuhan-morsi-dan-kegagalan-gerakan-islamis.html

Hasan Al-Banna, 2001, Risalah Pergerakan Ikhwanul Muslimin, Terj. Anis Mata, Solo:Intermedia.

Iran Indonesia Radio. 2014. 'Pendukung Ikwanul Muslimin di Mesir Gelar Demo', dalam Iran Indonesia Radio, dilihat 24 mei 2020 dari http://indonesian.irib.ir/international/afrika/item/80098Pendukung Ikwanul_Muslimin_di_Mesir_Gelar_Demo.

Islam Pos. 2014. 'Inilah 10 Kesalahan yang Dianggap Penyebab Digulingkannya Mursi', dalam Islampos.com, dilihat 24 Mei 2020, dari http://www.islampos.com/inilah-10-kesalahan-yang-dianggappenyebab-digulingkannya-mursi-66118

Jamil, Ahmad Islamy \& Mardiani, Dewi. 2013. 'Mesir Desak PBB Masukan IM ke Daftar Teroris', dalam Republika.co.id, dilihat 24 Mei 2020, dari https://www.republika.co.id/berita/internasional/global/13/12/27/ myfwpp-mesir-desak-pbb-masukan-im-ke-daftar-teroris

Jemadu, Liberty. 2014. 'Ikhwanul Muslimin Adukan Militer Mesir ke Mahkaham Kriminal Internasional', dalam Beritasatu.com, dilihat 4 Juni 2020, dari http://www.beritasatu.com/dunia/159102ikhwanul-muslimin-adukan-militer-mesir-ke-mahkaham-kriminalinternasional.html

Kisihandi, Ferry. 2014. 'Qatar Minta Tokoh Ikhwanul Muslimin Pergi, dalam Republika.co.id, dilihat 4 Juni 2020, dari https://www.republika.co.id/berita/koran/internasionalkoran/14/09/15/nbxoyg-qatar-minta-tokoh-ikhwanul-muslimin- pergi

Mahmud, Jami', 2004, Ikhwanul Muslimin "Yang Saya Kenal". Jakarta: Pustaka Al-Kautsar.

Muaz. A 2010 "membincang gurita islam transnasional" dalam academia.edu, dilihat pada 25 April https://www.academia.edu/3584102/Islam_Transnasional

Paulus, Loudewijk F. 2002. 'Terorisme', dalam Bulettin Balitbang Dephan, Volume V, Nomor 8 dilihat 24 Mei 2020, dari http://buletinlitbang.dephan.go.id.

Pengertian Ahli. 2014. 'Pengertian Strategi Menurut para Ahli', dalam Pengertianahli.id, dilihat 24 Mei 2020, dari http:/ / www.pengertianahli.com/2013/12/pengertian-strategimenurut-para-ahli.html\#

Porta, Donatella Della (editor), 2009, Democracy In Social Movements, New York : Martin's Press.

Puspitasari, Irfa. 2012. Dalam kuliah umum "Strategi Mobilisasi Masyarakat Sipil Global”, Surabaya : Universitas Airlangga 
Rachmat, Angga Nurdin, "Realisme Dalam Kebijakan Penolakan Pengungsi Dan Migran Oleh Hungaria Tahun 2015-2018” Jurnal Dinamika Global Vol. 5 No. 1, Juni 2020

Ramadan, Tariq, 2012, Islam and the arab awakening, New York : Oxford University Press.

Richard, Mitchel, 1969, The Society of Muslim Brotherhood, London: Oxford University Press.

Rubin, Barry (editor), 2003, Revolutionaries and reformers : contemporary Islamist movements in the Middle East, New York: State University of New York.

Rubin, Barry (editor), 2010, Guide to Islamist movements, New York : M.E.Sharpe.

Rubin, Barry (editor), 2010, The Muslim Brotherhood : the organization and policies of a global Islamist movement, New York : Martin's Press.

Saharuddin. 2015. Nilai Kultur Inti dan Institusi Lokal Dalam Konteks Masyarakat Multi-Etnis. Bahan Diskusi Tidak Diterbitkan. Depok: Program Pascasarjana Universitas Indonesia.

Setyawan, Eko Huda. 2013. '10`Dosa'PenyebabMorsiDigulingkanMiliter Mesir', dalam Liputan6.com, dilihat 10 Juni 2020, dari http://news.liputan6.com/read/631367/10-dosa-penyebab-morsidigulingkan-militer-mesir

Sinai Mesir. 2013. 'Jejak Rekam Pembubaran Ikhwanul Muslimin', dalam Sinaimesir.net, dilihat 24 Mei 2020, dari http://www.sinaimesir.net/2013/09/jejak-rekam-pembubaranikhwanul.html

Tarrow, Sidney, 2005, The New Transnational Activism, Cambridge: Cambridge University Press.

Utsman Abdul Mu'iz Ruslan, 2000, Pendidikan Politik Ikhwanul Muslimin: Studi Analisis Evaluatif terhadap Proses Pendidikan Politik Ikhwan untuk para Anggota khususnya dan seluruh Masyarakat Mesir Umumnya, dari tahun 1928 hingga 1945. Solo :Era Intermedia.

Voice of America. 2013. 'Mesir Nyatakan Ikhwanul Muslimin sebagai Kelompok Teroris', dalam VOAIndonesia.com, dilihat 24 Mei 2020, dari https://www.voaindonesia.com/a/mesir-nyatakan-ikhwanulmuslimin-kelompok-teroris / 1817616.html

Wickham, Carrie Rosefsky, 2002, Mobilizing Islam: Religion, Activism, and Political Change in Egypt, New York : Columbia University Press.

Wiktorowicz, Quintan (editor), 2004, Islamic Activism : A Social Movement Theory Approach, Indianapolis : Indiana University Press. 
Yanuardi, Syukur, 2013, Presiden Mursi "Kisah Ketakutan Dunia Pada Ikhwanul Muslimin”. Jakarta: Hayyun Media. 